\title{
Heavy metals in the Antarctic scallop Adamussium colbecki
}

\author{
M. Mauri ${ }^{1}$, E. Orlando ${ }^{2}$, M. Nigro ${ }^{2}$, F. Regoli ${ }^{2}$ \\ ${ }^{1}$ Dipartimento di Biologia Animale, Università di Modena, via Università 4, I-41100 Modena, Italy \\ ${ }^{2}$ Dipartimento di Biomedicina Sperimentale Infettiva e Pubblica, Università di Pisa, via Volta 4, I-56100 Pisa, Italy
}

\begin{abstract}
Cu}, \mathrm{Fe}, \mathrm{Cr}, \mathrm{Cd}, \mathrm{Mn}$ and $\mathrm{Zn}$ concentrations were determined in different organs of the Antarctic scallop Adamussium colbecki (Smith) and compared with those found in Pecten jacobaeus L., a scallop of temperate waters, and with literature values for other Pectinidae. The digestive gland of $A$. colbecki was the target organ for $\mathrm{Cu}, \mathrm{Fe}, \mathrm{Cr}$ and $\mathrm{Cd}$, whereas $\mathrm{Mn}$ and $\mathrm{Zn}$ were found mainly in the kidney. $\mathrm{Cd}$ concentration in the digestive gland of $\mathrm{A}$. colbecki was higher than that in the same organ of $P$. jacobaeus, indicating a marked ability of the Antarctic scallop to concentrate this metal. However, in A. colbeckj renal concentrations of both $\mathrm{Mn}$ and $\mathrm{Zn}$ were considerably lower than those measured in $P$. jacobaeus and other Pectinidae, and may be related to the scarcity of concretions observed in its kidney.
\end{abstract}

\section{INTRODUCTION}

Better insight into the ecology of the Antarctic is today of great importance considering the increasing interest shown in the resources of this continent. Collecting new environmental data will serve as the baseline for evaluating future environmental impact of pollutants in this remote area.

This study is a first determination of heavy metal levels ( $\mathrm{Cu}, \mathrm{Fe}, \mathrm{Cr}, \mathrm{Cd}, \mathrm{Mn}, \mathrm{Zn}$ ) in a bivalve mollusc of the Antarctic Sea bottoms, Adamussium colbecki.

Bivalves are the classic organisms of choice for studies on heavy metal accumulation (Bryan 1976), because of their poor capability of regulating ion concentrations in internal fluids and of their high tolerance, metal ions being sequestered in excess of metabolic requirements (George 1980). Consequently, high accumulation values are observed without apparent toxic effects. Adamussium colbecki was chosen for 2 main reasons: (1) It is one of the largest bivalves in the Antarctic marine environment and makes up most of the benthic biomass (Nicol 1966a, b). Hence, this mollusc can be considered one of the most significant species in the area. (2) It is found throughout the Antarctic coasts and over a wide bathymetric range (Dell 1972). This is of interest for future comparisons with specimens from other research stations in the Antarctic. A. colbecki is a gonochoristic species and is closely related systematically to Pectinidae from temperate seas, such as Lissopecten, Pecten and Chlamys.
Pecten jacobaeus L., a hermaphroditic species of temperate waters, was used for comparison between Adamussium colbecki and other non-Antarctic scallops. Data on heavy metal levels in other species of Pectinidae were also used for comparison with $A$. colbecki.

\section{MATERIALS AND METHODS}

Adamussium colbecki (Smith), (superfam. Pectinoidea, fam. Amussidae), was sampled in Terranova Bay, Ross Sea, in austral summer 1987/88 during an Italian expedition to the Antarctic, supported by the Progetto Nazionale Antartico. Samples of $A$. colbecki collected by dredging from depth of 40 to $70 \mathrm{~m}$ were immediately frozen at $-30^{\circ} \mathrm{C}$ and maintained at this temperature until processed for heavy metal analysis.

In the laboratory, specimens were subdivided into 2 groups of 30 each. One group was used for organ metal analysis and the other to measure the relation between body weight and metal levels in the body. In the latter case, all soft parts of scallops with shell length between 4.2 and $7.9 \mathrm{~cm}$ were analysed. For Group 1, metals were determined in mantle, gills, gonad plus foot, kidney, digestive gland and muscle. After partial thawing the adductor muscle was dissected to enable opening of the valves; sex was determined for all individuals.

The bean-shaped gonads, mature at sampling time, were bright orange in females and yellowish in males. 
After determination of the total fresh weight of the soft parts, organs of scallops of the first group were dissected. For evaluating individual variations every sample processed for analysis consisted of a single whole organ, except for kidneys, which consisted of pooled samples from 3 individuals. Dry weight was determined after drying at $105^{\circ} \mathrm{C}$ for $24 \mathrm{~h}$.

Mineralization of the samples was carried out by wet digestion with concentrated (BDH Aristar) nitric acid first for $24 \mathrm{~h}$ at room temperature, then on a hot plate; the mineralized dry residue was then diluted in $2 \%$ nitric acid. The same digestion procedures were repeated for lobster standards (National Research Council Canada) to check the accuracy of the analytical methods.

Samples of Pecten jacobaeus (superfam. Pectinoidaea, fam. Pectinidae) with ripe gonads, collected in the northern Adriatic Sea in June 1988, were processed for metal analysis using the same methodologies described for organs of Adamussium colbecki.

Analysis was by atomic absorption spectrophotometry (AAS) (IL mod. S11 equipped with a deuterium background corrector and an IL mod. 755 graphite furnace). $\mathrm{Cu}, \mathrm{Cr}$ and $\mathrm{Cd}$ were determined by carbon rod, Fe, Mn and $\mathrm{Zn}$ by flame atomization.

The mean percentage contribution of each organ to the total metal body burden was computed in order to compare metal content in the organs. Univariate analysis of variance (ANOVA) was applied to evaluate metal differences between males and females in gonads and in total body. A regression analysis was developed to assess the influence of body size on metal concentrations.

Samples of digestive gland fixed in situ (Antarctic) with buffered $10 \%$ formalin were cut into pieces of $1 \mathrm{~mm}$ and washed in $0.1 \mathrm{M}$ cacodylate buffer ( $\mathrm{pH}$ 7.3) with $8 \%$ sucrose added. Half of this material was postfixed in $1 \%$ osmium tetroxide. All samples were then dehydrated in ethanol and embedded in EponAraldite mixture and viewed in a Philips 400 electron. microscope fitted with an EDAX energy dispersive $\mathrm{X}$ ray analyzer.

Unstained sections of $300 \mathrm{~nm}$ were mounted on aluminium grids and used for X-ray microanalysis; sections of 70 to $100 \mathrm{~nm}$, stained with aqueous uranyl acetate and lead citrate, were used for conventional electron microscopy.

\section{RESULTS}

Concentrations of $\mathrm{Cu}, \mathrm{Fe}, \mathrm{Cr}, \mathrm{Cd}, \mathrm{Mn}, \mathrm{Zn}$ in organs and mean percentage contributions of each organ to the total metal body burden of the soft parts of both Adamussium colbecki and Pecten jacobaeus suggest that $\mathrm{Cu}, \mathrm{Fe}, \mathrm{Cr}$ and especially $\mathrm{Cd}$ in both species are mainly concentrated in the digestive gland, and that this organ contributes the highest percentage to the total body burden (Table 1). Although the organs of $P$. jacobaeus usually showed higher concentrations of metals, A. colbecki showed a strong accumulation of $\mathrm{Cd}$ in the digestive gland: the value is more than 3 times that measured in $P$. jacobaeus (Fig. 1). Mn and $\mathrm{Zn}$ were found mainly in the kidney (Table 1); in $A$. colbecki, the concentrations of $\mathrm{Mn}$ and $\mathrm{Zn}$ are respectively 400 and 14 times lower than in $P$. jacobaeus (Figs, 2 and 3). This explains the different percentage contribution of kidney to the total metal body content (12 and $5.3 \%$ in $A$. colbecki for $\mathrm{Mn}$ and $\mathrm{Zn}$ respectively; 60.9 and $23.3 \%$ in $P$. jacobaeus).

Males and females of Adamussium colbecki showed similar body concentrations of metals. However, female gonads contained higher $\mathrm{Cd}$ concentrations than males (Table 2). The female portion of the hermaphrodite

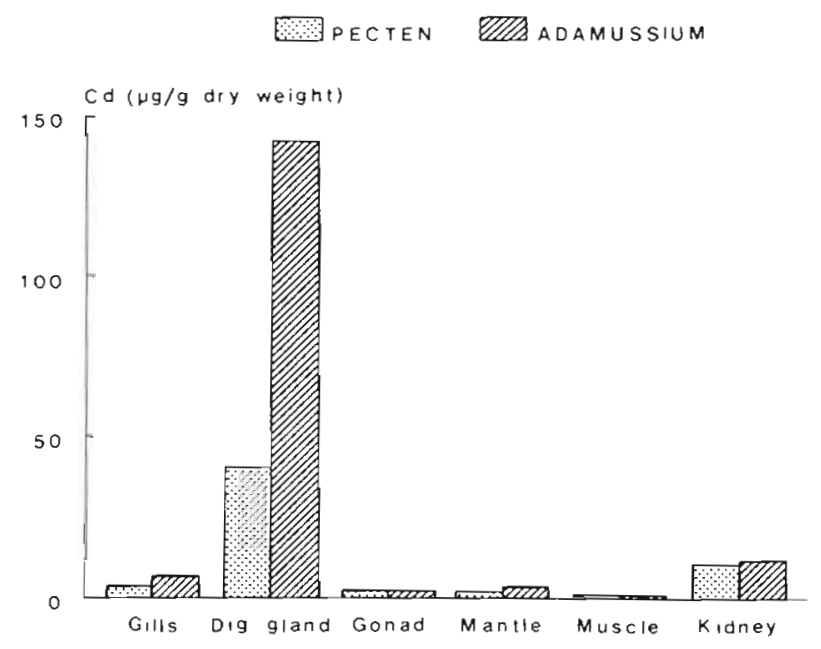

Fig. 1. Adamussium colbecki and Pecten jacobaeus. Cadmium concentrations in the organs

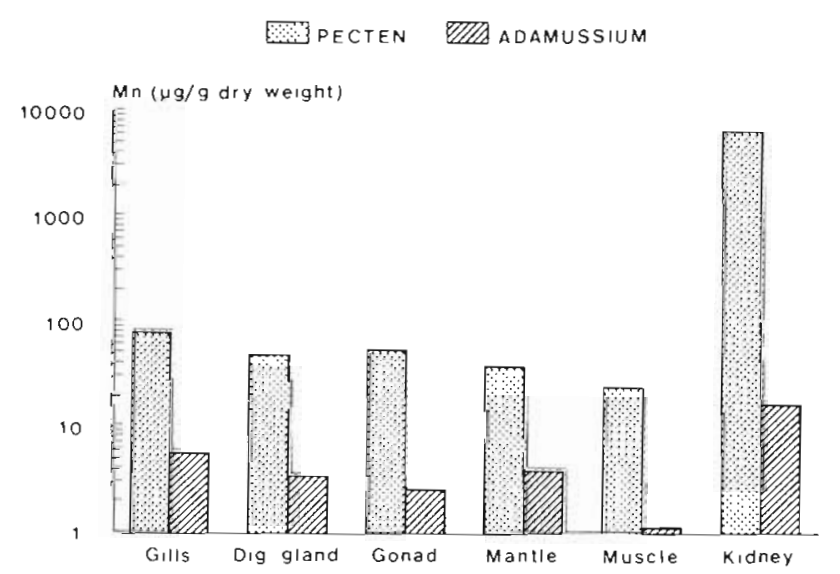

Fig. 2. Adamussium colbecki and Pecten jacobaeus. Manganese concentrations in the organs 
Table 1 Adamussium colbecki and Pecten jacobaeus. Heavy metals in the organs (1987/88). $\overline{\mathrm{x}}$ : mean concentration ( $\mu \mathrm{g} \mathrm{g}^{-1} \mathrm{dry}$ $w t)_{i}$ SD: standard deviation; \%: mean percentage contribution of the organs to the total metal body burden (soft parts)

\begin{tabular}{|c|c|c|c|c|c|c|c|}
\hline \multirow[t]{2}{*}{ Metal } & \multirow[t]{2}{*}{ Organ } & \multicolumn{3}{|c|}{ Adamussium colbecki } & \multicolumn{3}{|c|}{ Pecten jacobaeus } \\
\hline & & $\bar{x}$ & SD & $\%$ & $\bar{x}$ & SD & $\%$ \\
\hline \multirow{6}{*}{$\mathrm{Cu}$} & Gills & 6.5 & 2.2 & 12.3 & 6.3 & 2.1 & 10.8 \\
\hline & Dig. gland & 12.6 & 3.3 & 50.3 & 16.6 & 6.1 & 38.0 \\
\hline & Gonad & 4.7 & 2.2 & 8.0 & 10.3 & 3.8 & 24.6 \\
\hline & Mantle & 3.5 & 1.8 & 10.1 & 3.3 & 0.9 & 11.7 \\
\hline & Muscle & 1.6 & 0.9 & 17.5 & 1.1 & 0.3 & 12.2 \\
\hline & Kidney & 4.0 & 1.7 & 1.7 & 17.5 & 10.9 & 2.7 \\
\hline \multirow{6}{*}{$\mathrm{Fe}$} & Gills & 119 & 45 & 10.9 & 593 & 184 & 17.0 \\
\hline & Dig. gland & 292 & 63 & 56.6 & 1350 & 457 & 52.0 \\
\hline & Gonad & 87.9 & 36.1 & 7.3 & 181 & 62 & 7.3 \\
\hline & Mantle & 62.5 & 27.1 & 8.9 & 256 & 89 & 15.1 \\
\hline & Muscle & 28.4 & 8.1 & 14.9 & 41.0 & 16.0 & 7.7 \\
\hline & Kidney & 69.2 & 31.7 & 1.4 & 336 & 152 & 0.9 \\
\hline \multirow{6}{*}{$\mathrm{Cr}$} & Gills & 0.88 & 0.05 & 10.0 & 1.7 & 0.7 & 10.2 \\
\hline & Dig. gland & 1.7 & 0.4 & 40.4 & 4.8 & 2.8 & 38.4 \\
\hline & Gonad & 0.82 & 0.28 & 8.5 & 2.3 & 1.0 & 19.5 \\
\hline & Mantle & 0.95 & 0.05 & 17.0 & 1.5 & 0.4 & 18.5 \\
\hline & Muscle & 0.31 & 0.09 & 20.2 & 0.33 & 0.11 & 13.2 \\
\hline & Kidney & 1.5 & 0.5 & 3.9 & 0.33 & 0.15 & 0.2 \\
\hline \multirow{6}{*}{$\mathrm{Cd}$} & Gills & 6.8 & 1.1 & 2.1 & 3.7 & 1.9 & 5.0 \\
\hline & Dig gland & 142 & 57 & 93.1 & 41.0 & 18.2 & 73.6 \\
\hline & Gonad & 2.4 & 1.7 & 0.7 & 2.4 & 1.2 & 4.5 \\
\hline & Mantle & 3.5 & 0.9 & 1.7 & 2.0 & 0.6 & 5.4 \\
\hline & Muscle & 0.94 & 0.34 & 1.7 & 1.2 & 0.4 & 10.3 \\
\hline & Kidney & 11.6 & 3.3 & 0.8 & 10.7 & 4.0 & 1.3 \\
\hline \multirow{6}{*}{$\mathrm{Mn}$} & Gills & 5.7 & 1.5 & 18.1 & 53.1 & 24.5 & 5.6 \\
\hline & Dig. gland & 3.4 & 1.2 & 22.9 & 49.0 & 23.0 & 7.0 \\
\hline & Gonad & 2.5 & 1.0 & 7.3 & 54.0 & 29.2 & 8.0 \\
\hline & Vantle & 3.8 & 1.1 & 19.1 & 8.1 & 3.4 & 1.8 \\
\hline & Muscle & 1.1 & 0.6 & 20.6 & 23.9 & 14.3 & 16.7 \\
\hline & Kidney & 16.3 & 8.9 & 12.0 & 6390 & 3030 & 60.9 \\
\hline \multirow{6}{*}{ Zn } & Gills & 114 & 33 & 13.2 & 60.7 & 20.8 & 5.6 \\
\hline & Dig. gland & 74.9 & 25.4 & 18.3 & 124 & 55 & 15.4 \\
\hline & Gonad & 98.7 & 20.7 & 10.3 & 97.1 & 25.0 & 12.6 \\
\hline & Mantle & 123 & 46 & 22.3 & 63.7 & 37.4 & 12.1 \\
\hline & Muscle & 46.2 & 13.0 & 30.6 & 50.6 & 11.6 & 30.9 \\
\hline & Kidney & 199 & 89 & 5.3 & 2790 & 1340 & 23.3 \\
\hline
\end{tabular}

PECTEN THADAMUSSIUM

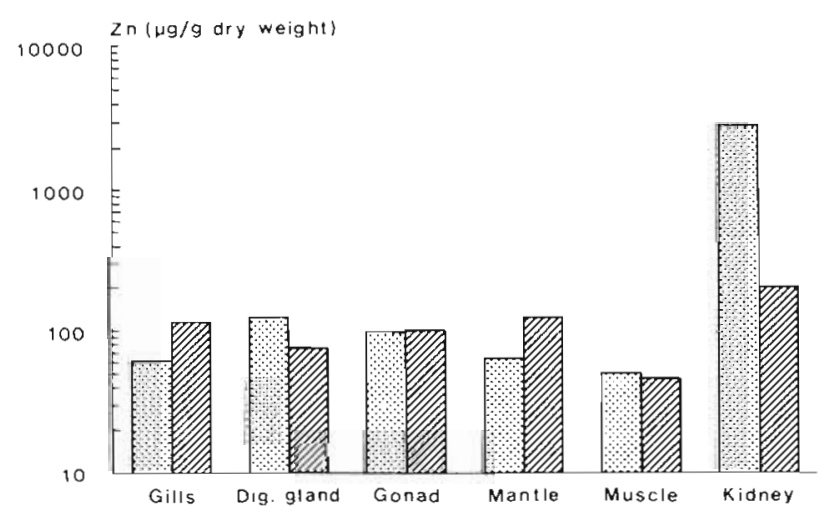

Fig. 3. Adamussium colbecki and Pecten jacobaeus. Zinc concentrations in the organs gonad of Pecten jacobaeus showed significantly higher concentrations of $\mathrm{Cu}$ and $\mathrm{Zn}$ than that of the male (Table 2).

Body size expressed as total dry weight of soft parts correlated with whole body soft part concentrations of $\mathrm{Cd}, \mathrm{Mn}$ and $\mathrm{Zn}$ in Adamussium colbecki (Table 3), whereas it did not affect $\mathrm{Cu}, \mathrm{Fe}$ and $\mathrm{Cr}, \mathrm{Cd}, \mathrm{Mn}$ and $\mathrm{Zn}$ decreased as body weight increased, as shown by double logarithmic coordinates (Fig. 4).

A characteristic feature of the digestive cell in Adamussium colbecki was the presence of a highly developed lysosomal system, composed of primary lysosomes, heterophagosomes and residual bodies. $\mathrm{X}$ ray microanalysis showed $\mathrm{Fe}$ and $\mathrm{Cu}$, which were constantly associated with heterophagosomes, whereas Zn was present mainly in the residual bodies. $\mathrm{Cr}, \mathrm{Cd}$ and 
Table 2. Adamussium colbecki and Pecten jacobaeus. Differences in metal concentrations between male and female gonads results of ANOVA. Only those metals with significant differences at 0.05 level are reportedi there was no significant difference in concentrations of $\mathrm{Fe}, \mathrm{Cr}$, and $\mathrm{Mn} . \overline{\mathrm{x}}$ : mean concentration $\left(\mu \mathrm{g} \mathrm{g}^{-1} \mathrm{dry} \mathrm{wt}\right.$ ); df: degrees of freedom

\begin{tabular}{|c|c|c|c|c|c|c|c|c|}
\hline \multirow[t]{2}{*}{ A. colbecki } & \multicolumn{4}{|c|}{$\mathrm{Cd}$} & & & & \\
\hline & $\bar{x}$ & F & $\mathrm{df}$ & $\mathrm{p}$ & & & & \\
\hline $\begin{array}{l}\text { Female gonad } \\
\text { Male gonad }\end{array}$ & $\begin{array}{l}4.2 \\
1.6\end{array}$ & 7.6 & 11 & $<0.01$ & & & & \\
\hline \multirow[t]{2}{*}{ P. jacobaeus } & \multicolumn{4}{|c|}{$\mathrm{Cu}$} & \multicolumn{4}{|c|}{$\mathrm{Zn}$} \\
\hline & $\overline{\mathrm{x}}$ & $\mathrm{F}$ & $\mathrm{df}$ & $\mathrm{p}$ & $\overline{\mathrm{x}}$ & $F$ & $\mathrm{df}$ & $\mathrm{p}$ \\
\hline $\begin{array}{l}\text { Female gonad } \\
\text { Male gonad }\end{array}$ & $\begin{array}{r}11.2 \\
3.9\end{array}$ & 9.7 & 7 & $<0.05$ & $\begin{array}{l}139 \\
52.1\end{array}$ & 8.7 & 7 & $<0.05$ \\
\hline
\end{tabular}

Mn were not detected in the cells of the digestive gland.

X-ray microprobes also showed $\mathrm{Na}, \mathrm{Mg}, \mathrm{P}, \mathrm{Si}, \mathrm{S}, \mathrm{K}$, and $\mathrm{Ca}$ in heterophagosomes and residual bodies. $\mathrm{Si}$ appeared to be confined to small needle-like particles contained within lysosomal vesicles (Fig. 5).

\section{DISCUSSION}

Metal concentrations in bivalves usually vary with biological factors such as body size (age) and sex. According to Boyden (1974) the influence of body size can be expressed by a power function

$$
[\text { metal }]=\mathrm{aw}^{\mathrm{b}}
$$

or:

$$
[\text { metal }] \mathrm{w}^{-1}=\mathrm{aw}^{\mathrm{b}-1}
$$

where $[$ metal $]=$ soft body metal content $;[$ metal $] w^{-1}=$ metal concentration in $\mu g g^{-1}$ dry $w t ; w=$ body weight (in g); and $\mathrm{a}$ and $\mathrm{b}=$ constants.

On a double logarithmic scale Eq. (2) gives the following straight line relation:

$$
\log [\text { metal }] w^{-1}=\log a+(b-1) \log w
$$

In Adamussium colbecki, the regressions are significant only for $\mathrm{Cd}, \mathrm{Mn}$ and $\mathrm{Zn}$, the concentrations of these 3 metals decreasing steadily with body weight throughout the whole size range of samples. Similar relations with regression coefficients $(b-1)<0$ were found by Boyden (1977) for $\mathrm{Mn}$ and $\mathrm{Zn}$ in Pecten maximus. On the other hand, $\mathrm{Cd}$ displayed a positive regression coefficient in older individuals, probably due to accumulation of the metal within specific tissue'. Adamussium colbecki does not show a similar trend for $\mathrm{Cd}$ with respect to body size. In this scallop the relation between metal level and body size might be influenced by factors such as contamination of sampling area and physiological state of the individuals (Latouche \& Mix 1982, Fischer 1983).

When considering the total body, no differences in metal concentrations were found between males and females of Adamussium colbecki. However, gonadal concentrations of $\mathrm{Cd}$ were higher in females than in males. The female portion of the hermaphroditic gonad of Pecten jacobaeus showed higher concentrations of both $\mathrm{Mn}$ and $\mathrm{Zn}$ than the male. Differences in metal concentrations between males and females have previously been reported for the bivalve Choromytilus meridionalis (Watling \& Watling 1976, Orren et al. 1980). According to Latouche \& Mix (1982), the higher gonadal level of $\mathrm{Mn}$ and $\mathrm{Zn}$ in females of Mytilus edulis is related to gametogenesis. Females of the wedge shell Donax trunculus show higher $\mathrm{Mn}$ and $\mathrm{Zn}$ concentrations than males when the gonads are ripe (Mauri \& Orlando 1983). This is due to higher gonadal concentrations of these 2 metals in females compared to males

\begin{tabular}{|c|c|c|c|c|c|c|}
\hline Metal & a & $\begin{array}{c}\text { Intercept } \\
(\log a)\end{array}$ & $\begin{array}{l}\text { Regression } \\
\text { coefficient } \\
(b-1)\end{array}$ & $\begin{array}{c}\text { Correlation } \\
\text { coefficient } \\
\text { (r) }\end{array}$ & $n$ & $p$ \\
\hline $\mathrm{Cd}$ & 39.26 & 1.594 & -0.34 & 0.653 & 30 & $<0.001$ \\
\hline $\mathrm{Mn}$ & 6.09 & 0.785 & -0.55 & 0.804 & 30 & $<0.001$ \\
\hline $\mathrm{Zn}$ & 113.77 & 2.056 & -0.55 & 0.795 & 30 & $<0.001$ \\
\hline
\end{tabular}

Table 3. Adamussium colbecki. Statistical data on relation (Eq. 3) between metal body concentrations ( $\mathrm{gg} \mathrm{g}^{-1} \mathrm{dry}$ wt) and body wejght ( $g$ dry $w t$ ). Only regressions with $b-1 \neq 0$ are reported. n. number of individuals 


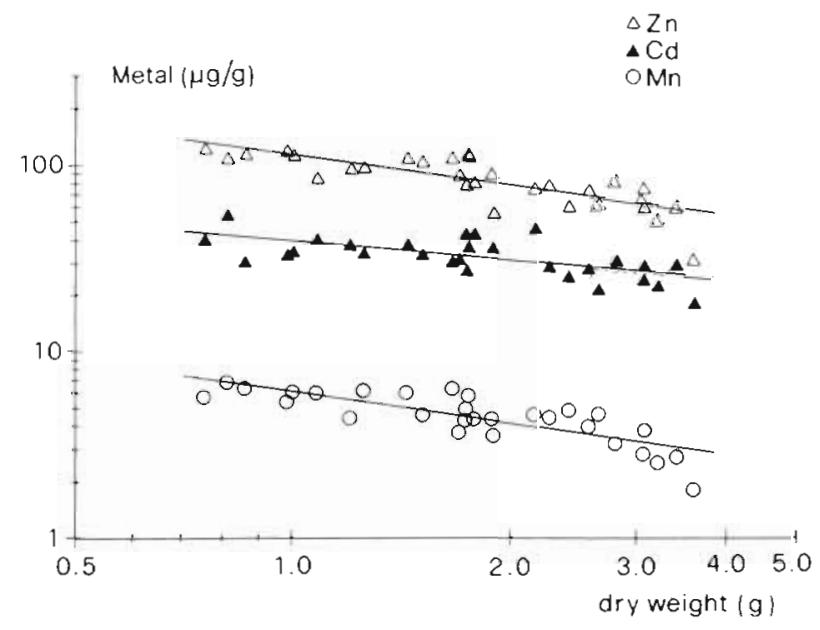

Fig. 4. Adamussium colbecki. Relation between metal concentrations ( $\mu \mathrm{g} \mathrm{g}^{-1}$ dry wt) and body weight. Only those regressions with $b-1 \neq 0$ are shown

The higher concentration of $\mathrm{Cd}$ in the female gonad of Adamussium colbecki might be related to the abundance of lysosomes in oocytes. The digestive gland of A. colbecki seems the target organ for $\mathrm{Cu}, \mathrm{Fe}, \mathrm{Cr}$ and $\mathrm{Cd}$, whereas $\mathrm{Mn}$ and $\mathrm{Zn}$ tend to accumulate in kidneys.

$X$-ray microanalysis of the digestive gland showed that $\mathrm{Cu}, \mathrm{Fe}$ and $\mathrm{Zn}$ are compartmentalized within the lysosomal system, particularly in heterophagosomes and residual bodies. This finding confirms data from previous studies on the intracellular localization of these metals in Pectinidae (Ballan-Dufrancais et al. 1985) as well as in other molluscs (George 1983). Although a high level of $\mathrm{Cd}$ was detected by AAS in Adamussium colbecki digestive gland, this metal was not revealed in unstained sections by X-ray microanalysis. This failure could be explained by the fact that $\mathrm{Cd}$ is mainly present in the cytosol, bound to thioneine-like proteins (Viarengo et al. 1987). However a selective loss of $\mathrm{Cd}$ during processing for electron microscopy cannot be excluded.

The abundant needle-like particles, which appear to be mainly composed of $\mathrm{Si}$, were also observed in Pecten maximus (Ballan-Dufrancais et al. 1985), and might be derived from sand or plankton organisms suspended in seawater. This finding also suggests that endocytosis probably occurs in Adamussium colbecki as in other filter-feeding bivalves: Pecten maximus (BallanDufrancais et al. 1985), Cardium edule (Owen 1970) and Mytilus edulis (Coombs 1980).

Metals were distributed between organs in a similar pattern in Adamussium colbecki and in Pecten jacobaeus. Concentrations in $A$. colbecki were lower, with the exception of $\mathrm{Cd}$ which is strongly accumulated in the Antarctic bivalve. It is surprising to find such high $\mathrm{Cd}$ concentrations in a species endemic to the Antarctic, where metal contamination appears unlikely. Therefore this high $\mathrm{Cd}$ level might represent a strong capacity in this species for concentrating this element. Variations in the ability to concentrate $\mathrm{Cd}$ have been described among members of the Pectinidae family. For example, Bryan (1973) suggested that differences between cadmium concentrations in $P$. maximus and Chlamys opercularis, collected from the same area of the English Channel, may be due to interspecific diversity.

Pectinidae strongly concentrate $\mathrm{Mn}$ and $\mathrm{Zn}$ in their kidneys (Table 4). While Pecten jacobaeus seemed to follow this pattern, Adamussium colbecki showed comparatively lower renal concentrations of $\mathrm{Mn}$ and $\mathrm{Zn}$. In fact, this organ made up a low percentage of the total body metal content ( $12 \% \mathrm{Mn}, 5.3 \% \mathrm{Zn})$ in A. colbecki, whereas the contribution was much higher $(60.9 \% \mathrm{Mn}$, $23.3 \% \mathrm{Zn}$ ) in $P$. jacobaeus. In this respect, $A$. colbecki is similar to Patinopecten yessoensis, which concentrates $\mathrm{Mn}$ and $\mathrm{Zn}$ to a low degree (Table 4). These low renal concentrations might be due to a low bioavailability of these 2 metals. For Mn, this hypothesis could be supported by the low levels in all other organs (Fig. $2)$, whereas in the case of $\mathrm{Zn}$, organ concentrations, with the exception of the kidney, appear similar to those in $P$. jacobaeus (Fig. 3). However we cannot exclude, as already seen for $\mathrm{Cd}$, interspecific diversity between the 2 scallops. It should be noted that $\mathrm{Mn}$ and $\mathrm{Zn}$ in the kidneys can be sequestered in intra- and extracellular concretions described in Pectinidae as well as in many other bivalves (Carmichael et al. 1979,

Table 4. Renal concentrations ( $\mu \mathrm{g} \mathrm{g}^{-1}$ dry wt) of $\mathrm{Mn}$ and $\mathrm{Zn}$ in Pectinidae

\begin{tabular}{|lccll|}
\hline & Mn & Zn & Sampling area & Source \\
\hline Chlamys opercularis & 17300 & 40800 & English Channel & Bryan (1973) \\
Pecten maximus & 15300 & 19300 & English Channel & Bryan(1973) \\
Pecten maximus & - & 32000 & Scotland & George et al. (1980) \\
Pecten novae-zelandiae & - & 2630 & New Zealand & Brooks \& Rumsby (1965) \\
Patinopecten yessoensis & 10 & 174 & Japan & Ishii et al. (1985) \\
Adamussium colbecki & 16 & 199 & Antarctic & Present study \\
Pecten jacobaeus & 6390 & 2790 & North Adriatic & Present study \\
\hline
\end{tabular}



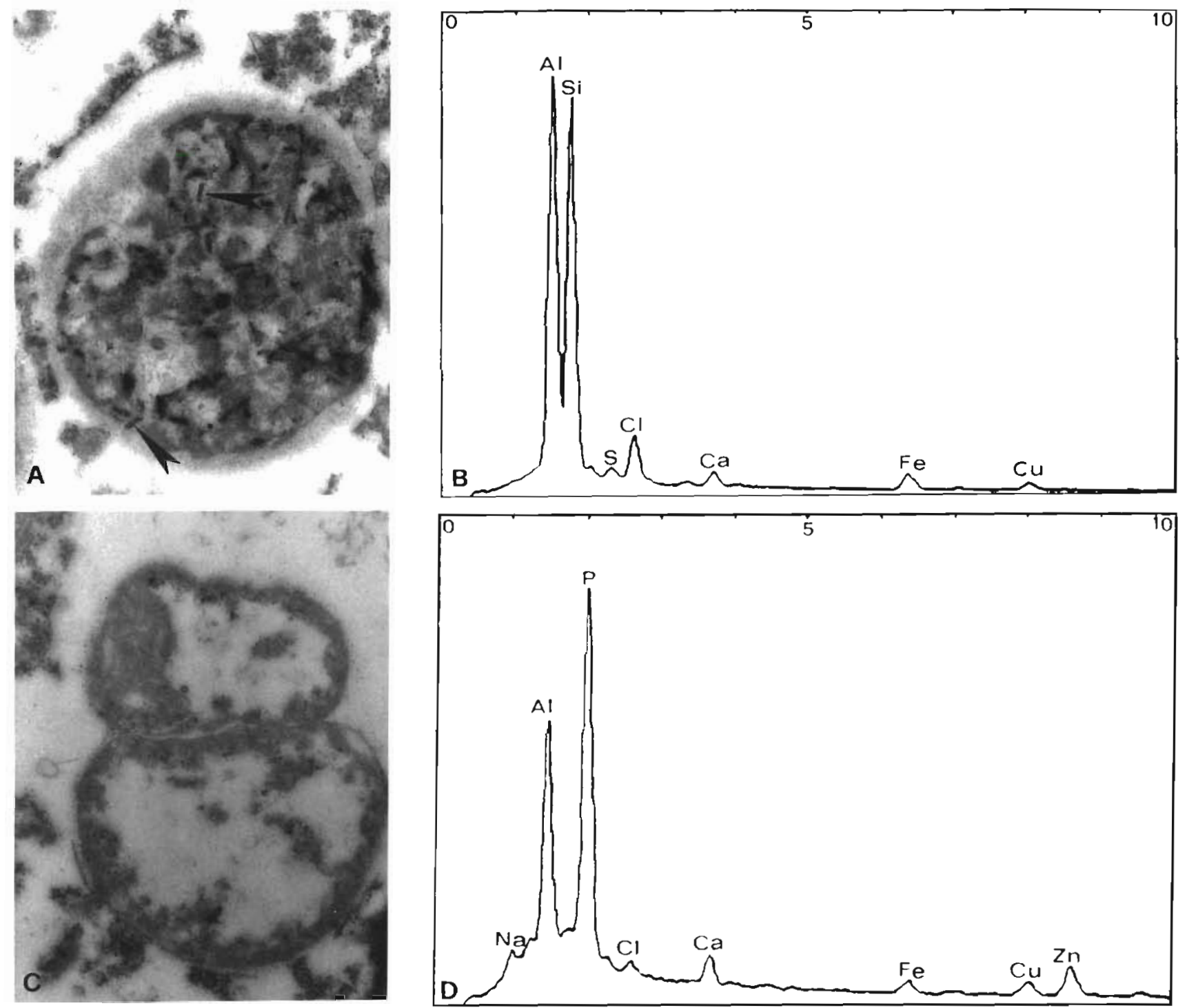

Fig. 5. Adamussium colbecki. Digestive gland. (A) Heterophagosome showing needle-like particles (arrowheads) ( $\times 20000) ;(B)$ typical X-ray spectrum from a heterophagosome; (C) residual body $(\times 20000)$; (D) typical X-ray spectrum from a residual body.

Al peak originates from the grid; horizontal scale $=X$-ray energy in $\mathrm{keV}$; vertical scale $=\mathrm{X}$-ray counts

George et al, 1980, Mauri \& Orlando 1982, Lucas \& Hignette 1983). These granules consist of phosphates and calcium with small amounts of other metals such as $\mathrm{Mn}, \mathrm{Zn}$, and Fe. In dissecting the scallops to isolate the kidneys for metal analysis large yellow-brown renal concretions were visible in almost every individual of $P$. jacobaeus, whereas the kidneys of $A$. colbecki did not show evident nephrolithes. Therefore, the difference in renal levels of $\mathrm{Mn}$ and $\mathrm{Zn}$ between the 2 scallops might depend on the amount of concretions present in the kidney.

Acknowledgements. Thus study was supported by Progetto Nazionale Antartico. We thank Prof. S. Bonotto for fruitful discussions and R. Menichini for technical assistance in X-ray mucroprobe analysis.

\section{LITERATURE CITED}

Ballan-Dufrancaıs, C., Jeantet, A. Y., Feghalı, C., Halpern, S. (1985). Physiological features of heavy metal storage in bivalve digestive cells and amebocytes: EPMA and factor analysis of correspondences. Biol. Cell. 53: 283-292

Boyden, C. R. (1974). Trace element content and body size in molluscs. Nature, Lond. 251: $311-314$

Boyden, C. R. (1977). Effect of size upon metal content of shellfish. J. mar bıol. Ass. U. K. 57: 675-714

Brooks, R. R., Rumsby, M. G. (1965). Biogeochemistry of trace element uptake by some New Zealand bivalves. Linnol. Oceanogr 10: 521-527

Bryan, G. W. (1973). The occurrence and seasonal variation of trace metals in the scallops Pecten maximus (L.) and Chlanys opercularis (L.). J. mar. biol. Ass. U.K. 53: $145-166$

Bryan, G. W. (1976). Some aspects of heavy metal tolerance in 
aquatic organisms. In: Lockwood, A. P. M. (ed.) Effects of pollutants on aquatic organisms. Academic Press, London, p. $7-34$

Carmichael, N. G., Squibb, K. S., Fowler, B. A. (1979). Metals in the molluscan kidney: a comparison of two closely related bivalve species (Argopecten) using $X$-ray microanalysis and atomic absorption spectroscopy. J. Fish. Res Bd Can. 36: 1149-1155

Coombs, T L. (1980). Heavy metal pollutants in the aquatic environment. In: Gilles R. (ed.) Animals and environmental fitness. Pergamon Press, Oxiord, p. 283-302

Dell, R. K. (1972). Antarctic benthos. Adv. mar. Biol. 10: 1-216

Fischer, H. (1983).Shell weight as an independent variable in relation to cadmium content in molluscs. Mar Ecol. Prog. Ser 12: $59-75$

George, S. G. (1980). Correlation of metal accumulation in mussels with the mechanisms of uptake, metabolism and detoxification: biochemical and ultrastructural studies Thalassia jugoslav. 16: $347-365$

George, S. G. (1983). Heavy metal detoxication in the mussel Mytilus edulis: composition of Cd containing kidney granules (tertiary lysosomes). Comp. Biochem. Physiol. 76: 53-58

George, S. G., Pirie, B. J. S., Coombs, T L. (1980). Isolation and elemental analysis of metal-rich granules from the kidney of the scallop Pecten maximus (L.). J. exp. mar Biol. Ecol. 42: 143-156

Ishii, T., Nakamura, R., Ishikawa, M., Koyanagi, T (1985). Determination and distribution of trace eleme nts in marine invertebrates. Bull. Jap. Soc. scient. Fish. 51: 609-617

Latouche, Y D., Mix, M. C. (1982). The effects of depuration,

This article was presented by Professor S. Bonotto, Mol, Belgium size and sex on trace metal levels in bay mussels. Mar Pollut. Bull. 13: 27-29

Lucas, A., Hignette, M. (1983). Les concrétions renales chez les brvalves marins: études anciennes et récents. Haliotis 13: $99-113$

Maur, M., Orlando, E. (1982). Expermental study on renal concretions in the wedge shell Donax trunculus L. J. exp. mar Biol. Ecol. 63: 47-57

Mauri, M., Orlando, E. (1983). Variabillty of zinc and manganese concentrations in relation to sex and season in the bivalve Donax trunculus L. Mar Pollut. Bull. 14: 342-346

Nicol, D. (1966a). Descriptions, ecology and geographic distribution of some antarctic pelecypods. Bull. Am. Paleont $51: 41-43$

Nicol, D. (1966b). Size of pelecypods in recent marine faunas. Bull. Am. Paleont. 79: 109-113

Orren, M. J., Eagle, G. A., Hennig, H., Green, A. (1980). Variations in trace metal content of the mussel Choromytilus meridionalis (Kr.) with season and sex. Mar Pollut Bull. 11 253--257

Owen, G. (1970). The fine structure of digestive tubules of the marine bivalve Cardium edule. Phil. Trans. R. Soc. Lond. B 258: $245-260$

Viarengo, A., Moore, M. N., Mancinelli, G., Mazzucotelli, A. Piper, K., Farrar, S. V (1987). Metallothioneins and lysosomes in metal toxicity and accumulation in marine mussels: the effect of cadmium in the presence and absence of phenanthrene. Mar Biol. 94: 251-257

Watling, H. R., Watlıng, R J. (1976). Trace metals in Choromytilus meridionalis. Mar Pollut. Bull. 7. 91-94

Manuscript first received: May 8, 1990

Revised version accepted: July 12, 1990 